\title{
Huntington's chorea arising as a fresh mutation
}

\author{
M BARAITSER, J BURN, AND T A FAZZONE \\ Clinical Genetics Unit, Institute of Child Health, 30 Guilford Street, London WC1N IEH.
}

SUMMARY A patient is reported in whom Huntington's chorea resulted from a new mutation.

Well documented fresh mutations in Huntington's chorea are rarely reported. Stringent criteria were suggested by Stevens and Parsonage. ${ }^{1}$ They considered that both parents should be alive and shown on examination to be clinically normal, both parents should have reached an age when a carrier of the gene would have manifested features of the disease, and legitimacy should be confirmed. The final proof is the occurrence of the disease in the offspring of the person in whom the fresh mutation is said to have occurred. Shaw and Caro ${ }^{2}$ list the possible cases of fresh mutation reported to date. These number ten, though in only two was legitimacy confirmed. Clearly, fresh mutations are not common and it is particularly unusual for an individual case to satisfy the stringent criteria. It is important, however, that such cases are reported since their existence counters suggestions that mutation events do not occur and contradicts the clinical practice of insisting on a family history before accepting the diagnosis. This report adds a further well documented case to the literature.

\section{Case report}

When first seen at the age of 33 years, the proband had complained that her friends had observed her limping. On questioning, she had noticed clumsiness of the hands and a tendency to drop things easily. She was unable to walk straight and fell frequently. Some household chores caused difficulty, particularly those where it was necessary to use the stairs. She judged her concentration to be normal but her memory to be somewhat impaired. On examination, the proband was found to have continuous jerky

Received for publication 1 March 1983.

Accepted for publication 9 May 1983. movements, particularly when relaxed. The movements were choreiform, involving hands, legs, and face. She had no detectable dysphasia, but jerky dysarthria was evident. On formal testing, deficits were demonstrated in short and long term memory and in her ability to perform mental arithmetic. Eye movements were full but slow and the other cranial nerves were normal on examination. She was unable to maintain a grip or posture but there was no demonstrable weakness.

Reflexes were brisk and bilateral finger jerks were present. Her gait was poorly coordinated and unsteady. Heel-toe test was poorly performed owing to the involuntary movements.

Her father was aged 70 and her mother 71 . They were healthy, as were her four older sibs. The proband had trained as a nurse and was married to a security officer. She had given birth to three children; her eldest daughter was, at the age of 17 , having behaviour problems but had no neurological abnormalities. Both parents agreed to undergo a neurological examination. Despite their years, both mother and father were alert with good memory function and showed no neurological abnormalities.

The proband was reviewed 8 years after her original presentation, by which time she was confined to a wheelchair and had clearly deteriorated. The choreiform movements were worse and her memory for recent events was very poor. She was still able to make excellent social contact and was able to offer relevant answers to questions about her everyday life.

A CT scan showed caudate atrophy. Blood was collected from the proband and both parents and subjected to blood group and serum marker examination. Table $a$ and $b$ show the results. Table $c$ shows the calculation of probability based on these results. If we take a prior probability of 1 in 10 for nonpaternity, which, if anything, is an overestimate, and if we take a figure of 1 in 10000 for a random male being an unrecognised carrier of the gene, table $d$ gives the probabilities of paternity. 
TABLE (a) Blood groups, (b) serum proteins, (c) and (d) probability of paternity.

(a)

\begin{tabular}{llllllllllllll}
\hline Blood groups & $A B O$ & $M N$ & $S s$ & $P_{1}$ & $R h$ & $L u^{\mathrm{a}}$ & $K k$ & $F y^{\mathrm{a}}$ & $F y^{\mathrm{b}}$ & $J K^{\mathrm{a}}$ & $J K^{\mathrm{b}}$ & $X g^{\mathrm{a}}$ & $C o^{\mathrm{b}}$ \\
\hline Mother & $\mathrm{A} 2$ & $\mathrm{~N}$ & -+ & + & $\mathbf{R} 1 \mathbf{R} 1$ & - & -+ & + & + & + & - & + & - \\
Father & $\mathrm{A} 1$ & $\mathbf{M}++$ & + & $\mathbf{r} \mathbf{r}$ & - & -+ & - & + & - & + & + & - \\
Proband & $\mathrm{A} 2$ & $\mathrm{MN}++$ & + & $\mathbf{R} 1 \mathbf{r}$ & - & -+ & - & + & + & + & + & - \\
\hline
\end{tabular}

(b)

\begin{tabular}{|c|c|c|c|c|c|c|c|c|c|c|c|c|c|c|}
\hline Serum proteins & $H p$ & $T f$ & $P G D$ & $P G M$ & $A K$ & $A D A$ & $G P T$ & $P i$ & $G c$ & $\mathrm{Gm}$ & $K m$ & $E s D$ & $G L O$ & $A C P$ \\
\hline $\begin{array}{l}\text { Mother } \\
\text { Father } \\
\text { Proband }\end{array}$ & $\begin{array}{l}2-1 \\
2-2 \\
2-2\end{array}$ & $\begin{array}{l}C \\
C \\
C\end{array}$ & $\begin{array}{l}\mathbf{A} \\
\mathbf{A} \\
\mathbf{A}\end{array}$ & $\frac{1}{2}-1$ & $\begin{array}{l}1 \\
1 \\
1\end{array}$ & $\begin{array}{l}1 \\
1 \\
1\end{array}$ & $\begin{array}{l}2-1 \\
2-1 \\
2\end{array}$ & $\begin{array}{l}\text { M1 } \\
\text { M2Z } \\
\text { M1Z }\end{array}$ & $\begin{array}{l}1+1- \\
1- \\
1+1-\end{array}$ & $\begin{array}{l}+1+10 \\
-1 \\
-1\end{array}$ & $\begin{array}{l}-1 \\
-1 \\
-1\end{array}$ & $\begin{array}{l}1 \\
2-1 \\
2-1\end{array}$ & $\begin{array}{l}2 \\
2-1 \\
2-1\end{array}$ & $\begin{array}{l}\text { BA } \\
\mathbf{A} \\
\mathbf{A}\end{array}$ \\
\hline
\end{tabular}

(c)

\begin{tabular}{|c|c|c|}
\hline $\begin{array}{l}\text { Blood groups } \\
\text { and serum } \\
\text { protcins }\end{array}$ & $\begin{array}{l}\text { Putative father } \\
\text { is biological } \\
\text { father }\end{array}$ & $\begin{array}{l}\text { Putative father } \\
\text { is not biological } \\
\text { father }\end{array}$ \\
\hline 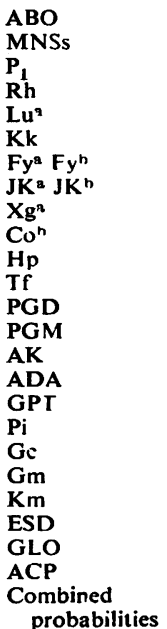 & $\begin{array}{l}0.3887 \\
0.5 \\
1.0 \\
1.0 \\
1.0 \\
1.0 \\
1.0 \\
1.0 \\
1.0 \\
1.0 \\
1.0 \\
1.0 \\
1.0 \\
0.5 \\
1.0 \\
1.0 \\
0.5 \\
0.5 \\
1.0 \\
1.0 \\
1.0 \\
0.5 \\
0.5 \\
1.0 \\
6.07343 \times 10^{-3}\end{array}$ & $\begin{array}{l}0 \cdot 7298 \\
0 \cdot 2371 \\
1 \cdot 0 \\
0 \cdot 38205 \\
0 \cdot 9610 \\
0 \cdot 9543 \\
0 \cdot 557 \\
0 \cdot 4858 \\
0 \cdot 9133 \\
0 \cdot 9588 \\
0 \cdot 6 \\
0 \cdot 9994 \\
0 \cdot 98097 \\
0 \cdot 75723 \\
0 \cdot 95947 \\
0 \cdot 94696 \\
0 \cdot 48996 \\
0.0141 \\
1.0 \\
0.66 \\
0.95 \\
0.09692 \\
0.44 \\
0.34684 \\
3.72475 \times 10^{-7}\end{array}$ \\
\hline
\end{tabular}

(d)

1. Assume prior probability of nen-paternity of $10 \%$

2. Assume probability of random male carrying gene 1 in 10000

If mutation rate $=1 \times 10^{-5}$, probability of paternity $=0.99998467$.

If mutation rate $=1 \times 10^{-6}$, probability of paternity $=0.9998467$.

If mutation rate $=1 \times 10^{-7}$, probability of paternity $=0.998469$.

If mutation rate $=1 \times 10^{-8}$, probability of paternity $=0.984899$.

\section{Discussion}

This family satisfies all but one of the criteria laid down by Stevens and Parsonage. ${ }^{1}$ Both parents were examined and shown to be neurologically normal, having reached an age at which there was less than $1 \%$ chance of being a carrier and not having manifested the disease. The normality of the proband's four older sibs added to the probability that the parents were not gene carriers. From personal knowledge of the family, true paternity was considered highly likely and this view was supported by examination of blood groups in the family members. It can be seen that paternity is 'proven' provided the mutation rate is at least 1 in $\mathbf{1 0}$ million. Even if the mutation rate for Huntington's chorea were as little as 1 in 100 million, the probability of paternity still exceeds $98 \%$. The clinical features in the proband were those of classical Huntington's disease and diagnosis was supported by the caudate atrophy evident on CT scan. The only criteria which was not satisfied was that of transmission of the disease Fortunately, there are as yet no neurological signs of the disease in her children though they are at relatively young and one has shown signs of disturbet behaviour.

This report confirms that fresh mutations do occur in Huntington's disease. Given the difficulties inherent in confirming new mutations, published reports must represent an underestimate of their true incidence.

We are grateful to Dr Ruth Sanger and the staff of MRC Blood Group Unit, University College London, for performing blood group analyses, and to Dr Gerald Corney and the staff of the MRC Human Biochemical Genetics Unit, The Galton Laboratory, University College London, for examining serum protein polymorphisms in this family.

\section{References}

1 Stevens D, Parsonage M. Mutation in Huntington's chorea. J Neurol Neurosurg Psychiatry 1969;32:140-3.

2 Shaw M, Caro A. The mutation rate to Huntington's chorea. J Med Genet 1982;19:161-7.

Correspondence and requests for reprints to Dr M Baraitser, Clinical Genetics Unit, The Hospital $\stackrel{\odot}{\rightarrow}$ for Sick Children, Great Ormond Street, London 0 WC1N 3JH. 